\title{
Late Maastrichtian foraminiferids and diatoms from the Polish Carpathians (Ropianka Formation, Skole Nappe): a case study from the Chmielnik-Grabówka composite section
}

\author{
M. ADAM GASIŃSKI ${ }^{1}$, ALEXANDRA OLSHTYNSKA ${ }^{2}$ AND ALFRED UCHMAN ${ }^{1}$ \\ IInstitute of Geological Sciences, Jagiellonian University, Oleandry 2a, PL-30-063 Kraków, Poland. \\ E-mails: adam.gasinski@uj.edu.pl,alfred.uchman@uj.edu.pl \\ ${ }^{2}$ Institute of Geological Sciences, National Academy of Sciences of Ukraine, O. Gonchara str. 55-b, 01601 \\ Kiev,Ukraine.E-mails:ol-lesia@mail.ru; ol-lesia@igs-nas.org.ua
}

\begin{abstract}
:
Gasiński, M.A., Olshtynska, A. and Uchman, A. 2013. Late Maastrichtian foraminiferids and diatoms from the Polish Carpathians (Ropianka Formation, Skole Nappe): a case study from the Chmielnik-Grabówka composite section. Acta Geologica Polonica, 63 (4), 515-525. Warszawa.

Well-preserved foraminiferids have been found in the Chmielnik-Grabówka section (Skole Nappe, Polish Carpathians). The Abathomphalus mayaroensis (late Maastrichtian) and Racemiguembelina fructicosa (earlylate Maastrichtian) standard planktonic foraminiferal biozones have been recognized, based on the occurrence of their respective index species. Sediments of the $R$. fructicosa Zone contain diatoms, which are a rare component of Cretaceous flysch microfossil assemblages in the Carpathians. The diatom frustules and some foraminiferid tests are pyritized, probably after burial in the sediment, below the redox boundary or in the oxygen-deficient microenvironment inside the frustules or tests of microfossils; the presence of trace fossils and bioturbational structures in the same bed indicate an oxygenated sea floor.
\end{abstract}

Key words: Carpathians; Skole Nappe; Cretaceous; Microfossils; Plankton; Foraminiferids; Diatoms; Flysch.

\section{INTRODUCTION}

Flysch sediments of the Carpathians are usually poor in diagnostic planktonic foraminiferids and, consequently, biostratigraphic resolution of many of their lithostratigraphic units is low. An exception is the 'Senonian'-Palaeocene of the Ropianka Formation in the Skole Nappe, which contain abundant planktonic foraminiferids, including index taxa for standard biozones (Gasiński and Uchman 2009, 2011a, b). The Gansserina gansseri Zone (late Campanian-early Maastrichtian) and the Abathomphalus mayaroensis Zone (late Maastrichtian) are commonly recognized whereas the Racemiguembelina fructicosa Zone (early-late Maastrichtian) is rarely distinguishable north of the Mediterranean region (Nederbragt 1991; Robaszynski and Caron 1995; Li and Keller 1998; Arz and Molina 2002; Premoli-Silva and Verga 2004; Pèrez-Rodrígues et al. 2012).

Well-preserved, partly pyritized foraminiferids of the R. fructicosa Zone, have been found in the ChmielnikGrabówka section of the Skole Nappe (Text-fig. 1). The zone also contains pyritized diatoms, which are rarely reported from the Cretaceous flysch microfossil 
assemblages in the Carpathians (Geroch and Nowak 1980). Although diatoms are a prominent group of modern phytoplankton, little is known about their ecological role in Cretaceous marine environments. This, in part, is due to the fact that diatom preservation is strongly controlled by taphonomic processes (Lohman 1960). The age and taxonomic composition of the microfossil assemblage reported herein make it a significant find. Its description and interpretation is the main aim of this paper as a contribution to the stratigraphy and palaeoecology of Upper Cretaceous flysch sediments.

\section{GEOLOGICAL SETTING}

The Skole Nappe is the most external major nappe of the Polish Flysch Carpathians on the northeastern bend of the Carpathian arc (Text-fig. 1A). It is composed of Lower Cretaceous-Miocene deep-sea sediments that accumulated in the Skole Basin of northern Neotethys and which were subsequently folded and thrust northward during the Miocene. The Upper CretaceousPalaeocene succession is dominated by turbiditic sediments of the Ropianka Formation (Kotlarczyk 1978 and references therein) (= the Inoceramian Beds in the older literature). It is overlain by Eocene deep-sea mudstone-dominated sediments of the Variegated Shale Formation (Rajchel 1990). The study region, south-east of Rzeszów, was described and mapped by Wdowiarz (1949), who distinguished lower, middle and upper levels in the Ropianka Formation (his Inoceramian Beds), which are together $500 \mathrm{~m}$ thick. Kotlarczyk (1978) subdivided the Ropianka Formation into the Cisowa Member (Turonian-lower Campanian), Wiar Member (lower Campanian-lower Maastrichtian), Leszczyny Member (lower Maastrichtian-Lower Palaeocene) and Wola Korzeniecka Member (Palaeocene) (Text-fig. 1C).

The Chmielnik-Grabówka composite section studied herein is located in the eastern part of the village of Chmielnik, along the Wylewna stream (right-hand tributary of the Chmielniczanka (Ryjak) stream) running through the hamlet Grabówka (hence its name). The geology and palacontology of the Chmielnik area was briefly documented by Friedberg $(1900,1903,1908)$, Grzybowski (1903), Kropaczek (1917), Chlebowski et al. (1937), Wdowiarz (1949), Bromowicz (1974) and Malata (2001). The upper part of the Ropianka Formation crops out in small, isolated exposures along the Wylewna stream (Text-fig. 1B). It contains mostly turbiditic beds composed of fine-grained, rarely medium- or coarse-grained calcareous sandstones in the lower part, which grade into grey and bluish-grey marls and marly mudstones in the upper part. The sandstones are muscovitic, mostly thin-bedded, parallel- and ripplelaminated, with sharp bases. Beds up to $1.5 \mathrm{~m}$ thick occur in some outcrops. Some beds contain abundant plant detritus, and others mud clasts. The thickness of the marls or marly mudstones is approximately equal to that of the sandstones (up to $1 \mathrm{~m}$ in some beds). Packages with thicker marls are distinguished as the " $\mathrm{Bac}$ ulites Marl", and form lensoidal lithosomes in the upper part of the Ropianka Formation (Wdowiarz 1949; Kotlarczyk 1978; Geroch et al. 1979). Locally, sandy mudstones contain blocks of sandstones. They are interpreted as debris flow deposits and are called the Makówka Slump Debris (Kotlarczyk 1985).

The studied deposits represent the Leszczyny Member of the Ropianka Formation sensu Kotlarczyk (1978, 1988). They belong to the Hadle Kańczuckie-Chmielnik Thrust Sheet, a complex structure, with four anticlinal elements and internal thrusts (Wdowiarz 1949). The complex tectonics suggests stratigraphic repetitions along the observed succession within the composite section studied. Consequently, the section was subdivided into three segments, A, B and C, each treated separately and then correlated biostratigraphically

\section{MICROFOSSILS}

The micropalaeontological analyses were based on 18 samples. Dried residuum was sieved, with a final sieve size of $0.063 \mathrm{~mm}$. The best specimens were identified and described using a Zeiss Stemi SV 11 stereomicroscope. Selected forms of foraminiferids and diatoms were studied and photographed by means of a scanning electron microscope (SEM (HITACHI S-4700 with EDS Vantage Noram).

\section{Planktonic foraminiferids}

Nearly all of the studied samples of the ChmielnikGrabówka section (CG1-CG15) (Text-fig. 2) contain well-preserved index planktonic species (Text-fig. 3). Two samples (CG1, CG2) of segment C yielded Abathomphalus mayaroensis (Bolli) (Text-fig. 4L, M), the index taxon of the eponymous zone of the upper Maastrichtian (Robaszynski and Caron 1995). Well-preserved specimens of this species are rarely found in the Carpathian Realm. Racemiguembelina fructicosa has

Text-fig. 1. Location map. A-location of the study area in the Skole Nappe. B - location of the investigated samples with indication of the orientation of beds as measured in the field. C - stratigraphic scheme of the Skole Nappe, with indication of the studied interval; based on Kotlarczyk (1988), Rajchel (1990), Gasiński and Uchman (2009, and references therein). TRShMb - Trójca Red Shale Member; VSh - Variegated Shale; ChSMb - Chmielnik Striped Sandstone Member 


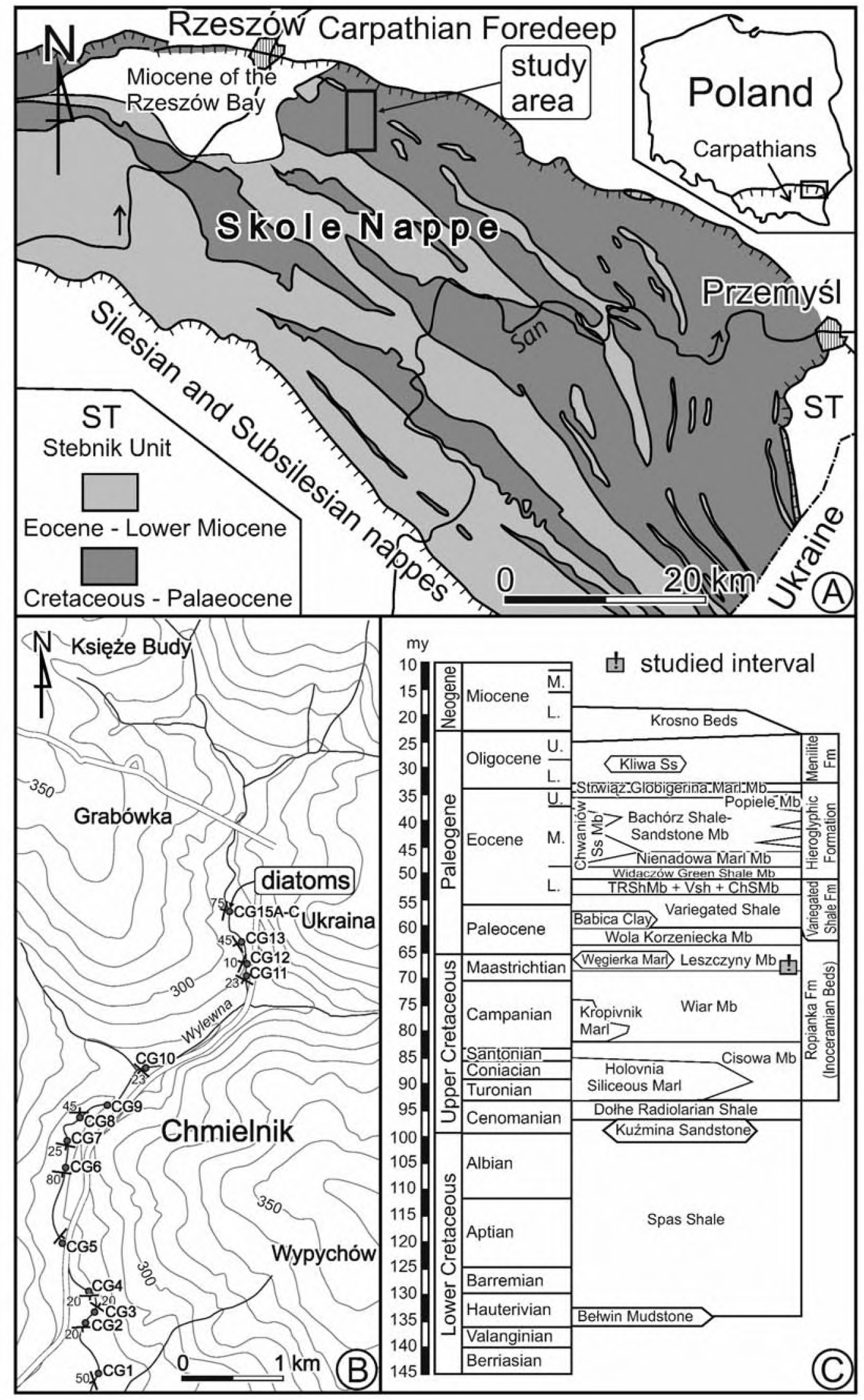



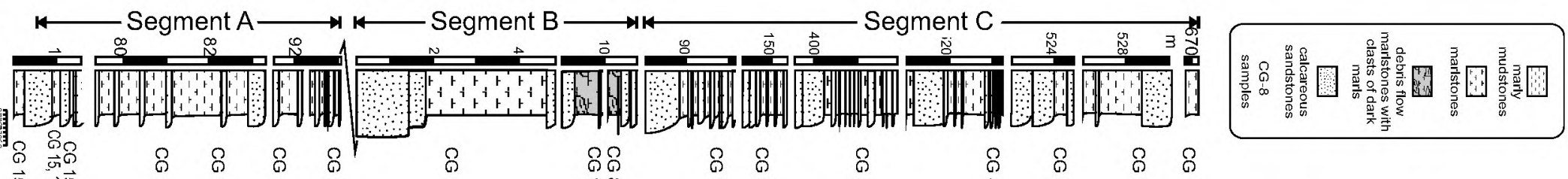

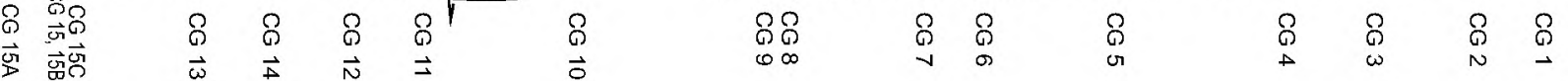
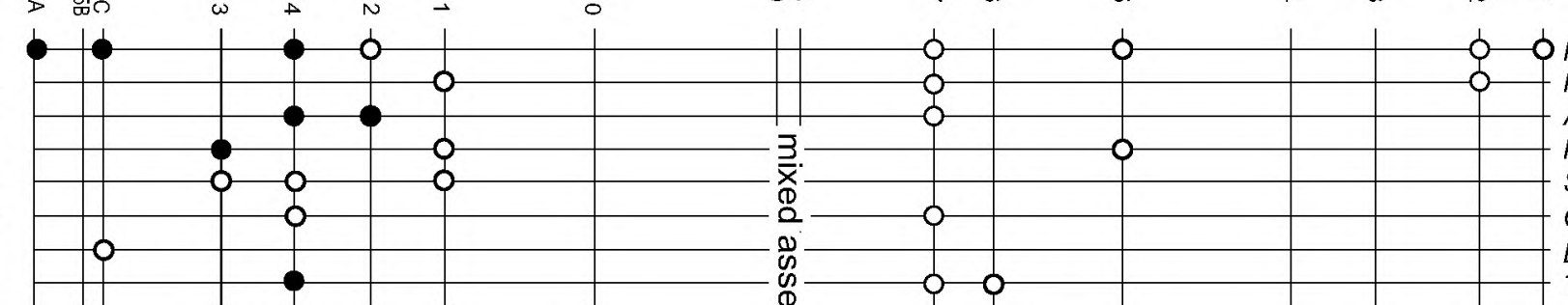

Rhabdammina sp., Nothia isp. Rzehakina spp.

Ammodiscus sp., Glomospira sp.

Karrerulina spp.

Spiroplectammina sp.

Caudammina gigantea

Bathysiphon sp.

Trochammina spp., Trochamminoides spp. Reussella szajnochae
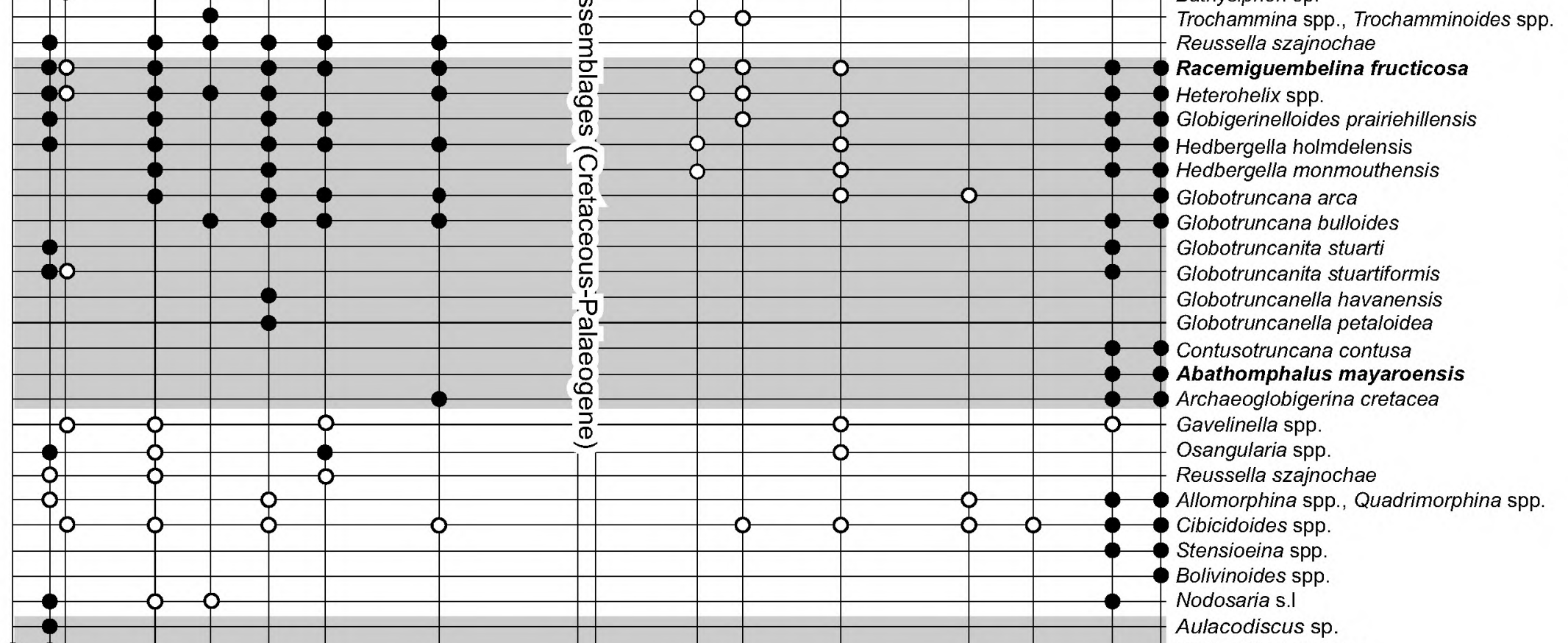

0

$\longleftarrow$ R. fructicosa $\longleftrightarrow \leftarrow$ R. fructicosa ? ? $\leftarrow$ Racemiguembelina fructicosa $\quad$ í Abm $\rightarrow$ Zones

$\longleftarrow$ R. fructicosa $\longleftrightarrow \leftarrow$ R. fructicosa $?$ ? $\leftarrow$ Racemiguembelina fructicosa $\quad$ í Abm $\rightarrow$ Zones

Contusotruncana contusa

Abathomphalus mayaroensis

Archaeoglobigerina cretacea

Gavelinella spp.

Osangularia spp.

Reussella szajnochae

Allomorphina spp., Quadrimorphina spp.

Cibicidoides spp.

Stensioeina spp.

Bolivinoides spp.

Aulacodiscus sp.

unidentified diatoms 
been identified in samples CG5-CG7 (segment C; Textfig. 2). This is the index species of the early-late Maastrichtian $R$. fructicosa Zone, preceding the A. mayaroensis Zone. Other epipelagic species, including Globigerinelloides prairiehillensis Pessagno, Hedbergella monmouthensis (Olsson) and Heterohelix spp., occur in high abundance in samples from the $R$. fructicosa Zone (Text-fig. 2). The foraminifers of sample CG15, which also contains pyritized diatoms, are relatively well-preserved and some of the planktonic foraminiferids are also pyritized. The pyritization is observed only among the tiny epipelagic Hedbergella spp.
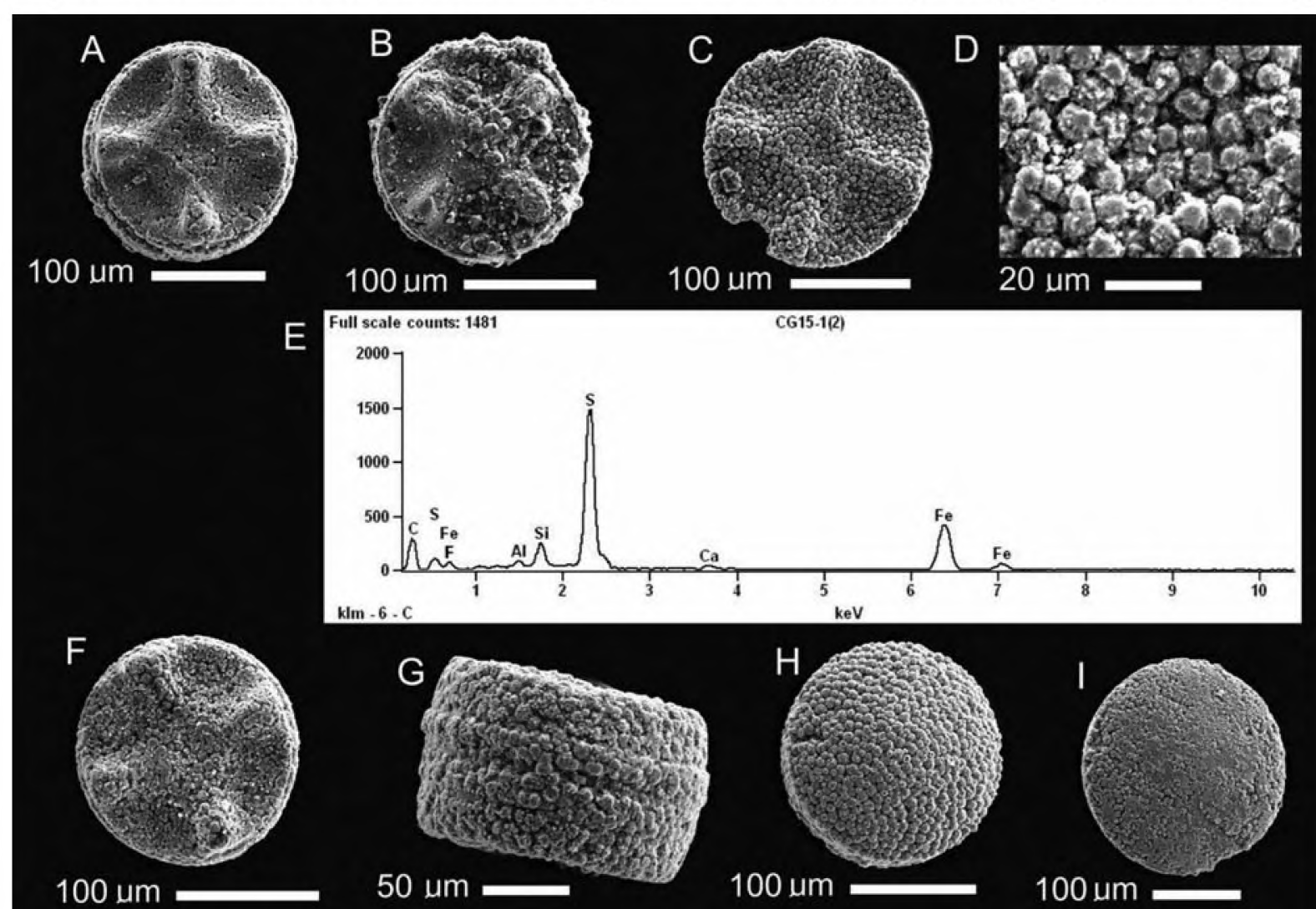

$\operatorname{lm}-6 \cdot \mathrm{C}$

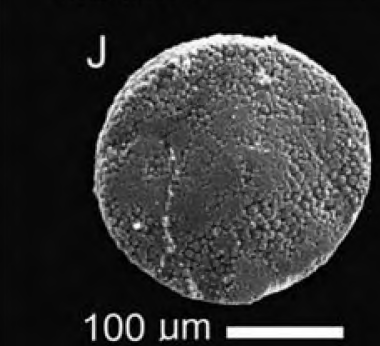

${ }^{50}$
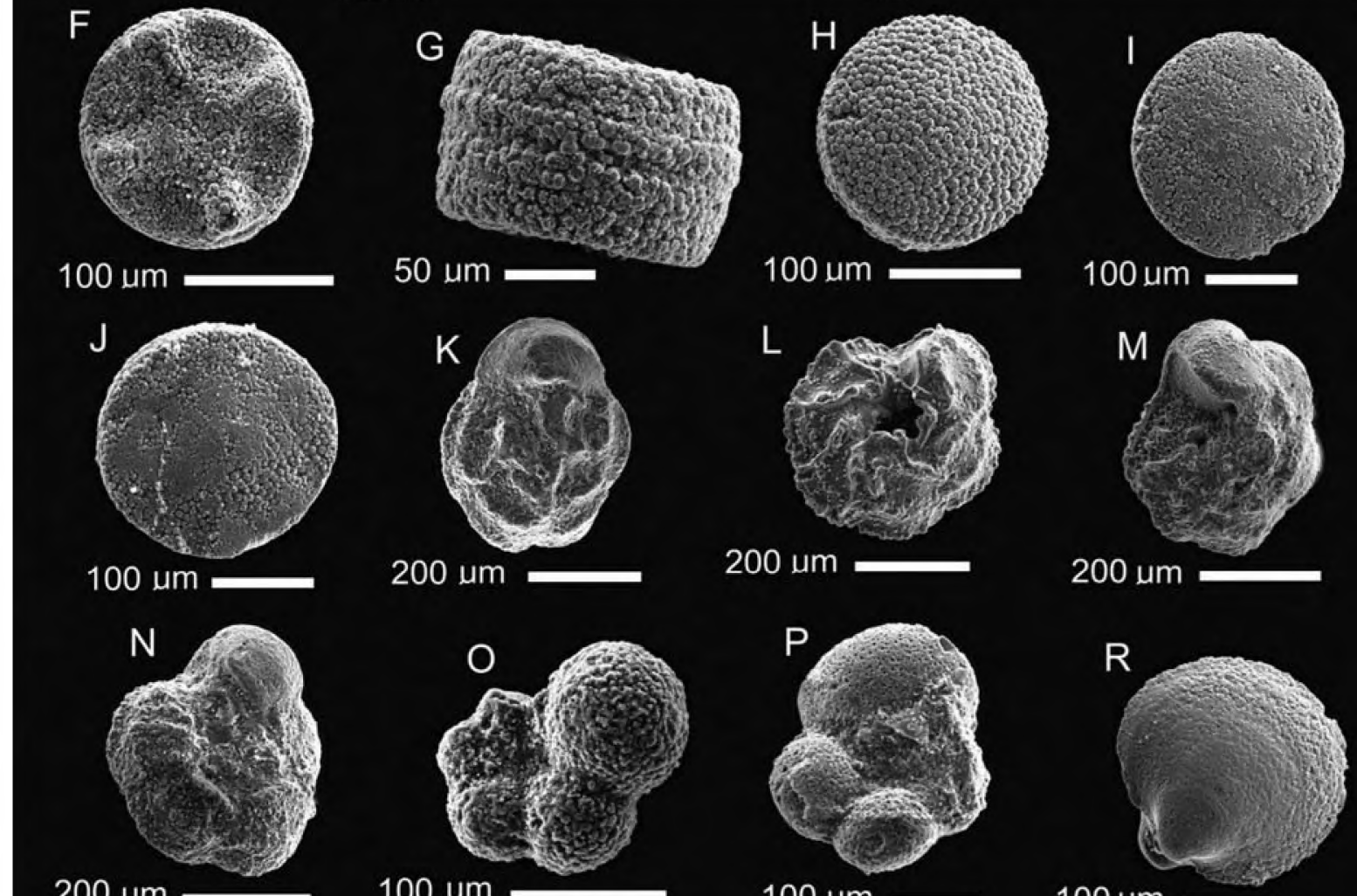

200 um

100 um
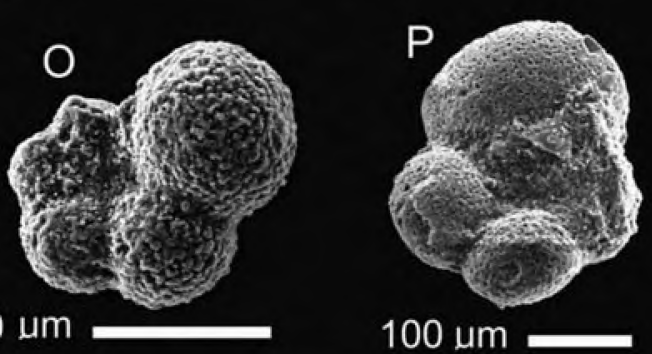

R

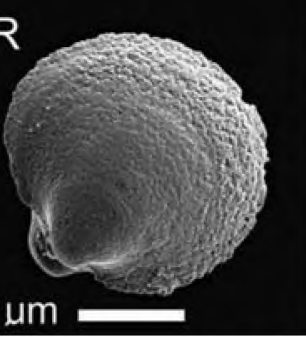

Text-fig. 3. Diatoms and foraminiferids from sample CG15, Chmielnik-Grabówka section. Diatoms: A - C, D, F -Aulacodiscus sp., E - EDS analysis of surface of diatom frustule shown in C. G-J - unidentified diatoms. Foraminiferids: $\mathbf{K}$ - Globotruncana arca Cushman. $\mathbf{L}$ - Globotruncanita cf. stuartiformis Dalbiez. $\mathbf{M}$ - Globotruncanita ef. stuarti (de Lapparent). $\mathbf{N}$ - Globotruncana bulloides Vogler. $\mathbf{O}$-Globigerinelloides prairiehillensis Pessagno. $\mathbf{P}$ - Globotruncanella havanensis (Vorrvijk). R - bivalve shell (glochidia?) 
and Globigerinelloides spp., with about $70 \%$ of the specimens pyritized. This sample falls within the earlylate Maastrichtian R. fructicosa Zone (Robaszynski and Caron 1995; Premoli-Silva and Verga 2004; Gasiński and Uchman 2011a, b). The most characteristic species in sample CG15 include R. fructicosa, Globotruncanita stuarti (de Lapparent), Globotruncanita stuartiformis (Dalbiez), Globotruncana arca Cushman, Globotruncana bulloides Vogler (Text-fig. 3) and Globigerinelloides prairiehillensis Pessagno (Text-fig. 30). Text-figs 3 and 4 show SEM micrographs of these species. Additionally, a few specimens of juvenile (larval stage) bivalve shells (glochidia?), fish teeth, as well as, fragment of crinoid cirri have been identified within sample CG15 (Text-figs 3R, 4A, B).

\section{Benthic foraminiferids}

Agglutinated foraminiferids are relatively rare, except for samples CG12 and CG14. They are dominated by the suspension feeder morphogroup sensu Jones and Charnock (1985), Nagy (1992) and Koutsoukos and Hart (1990). Rhabdammina sp. and Nothia sp. are abundant and constitute about $70 \%$ of the agglutinated foraminiferal assemblage. Less abundant are Trochammina spp., Trochamminoides spp., and Caudammina spp. (about $15 \%$ of the agglutinated foraminiferal assemblage) which belong to the epifaunal morphogroup. In samples CG11 and CG13, representatives of the infaunal morphogroup are rare, and include Spiroplectammina spp. and Karrerulina spp. Among the calcareous benthic foraminiferids, some species of Allomorphina, Stensioeina, Cibicidoides and Bolivinoides are dominant in samples CG1 and CG2 (ca. $15 \%$ of the whole foraminiferal assemblages), from the A. mayaroensis Zone (Text-fig. 2). These genera are mainly characteristic of the Boreal Domain (Gasiński 1997 and references therein), however, they are also represented by widespread species, especially in the North African Cretaceous sediments (e.g. Ayyad et al. 1997; Khalili 1998; Peryt et al. 2002). Their presence suggests an influence of Boreal waters in this part of the Skole Basin during the latest Maastrichtian (Gasiński and Uchman 2009, 2011a, b).

\section{Diatoms}

Ten diatom specimens, obtained together with the foraminifers, have been examined. They were yielded by samples CG15 ( 8 specimens) and CG15A ( 2 specimens), both from the basal part of segment A. Sample CG15 is from a $20-22$ cm-thick dark grey marl, which overlies (with a transition) a $65 \mathrm{~cm}$-thick, fine- grained sandstone with intraclasts at the base, and underlies a similar sandstone bed that is $20 \mathrm{~cm}$ thick. Sample CG15A was collected below the sandstone (Text-fig. 2).

All of the diatoms are completely pyritized (Text-fig. $3 \mathrm{E})$. The pyrite crystals entirely mask the fine structure of the frustules, making species-level identification impossible (Text-fig. 3C D, F, H). Four valves are 150-180 $\mu \mathrm{m}$ in diameter and display sectors arranged in a cruciform pattern (Text-fig. 3A-C, F). This general morphology is characteristic of the genus Aulacodiscus Ehrenberg, 1844 (Proschkina-Lavrenko 1949; Harwood and Nikolaev 1995; Strelnikova et al. 2004).

Diatoms from sample CG15 (Text-fig. 3G, H, I, J) are unidentifiable due to the absence of any diagnostic features. Lenticular frustules (Text-fig. 3G-J) are characteristic of a number of Late Cretaceous genera, including e.g., Stellarima, Nikolaevia and Coscinodiscus. Some specimens (Text-fig. H-J) have a diameter $150-200 \mu \mathrm{m}$, round shape and lenticular, convex valve faces. The specimen illustrated in Text-fig. $3 \mathrm{G}$ is represented by a cylindrical frustule, which is $180 \mu \mathrm{m}$ in diameter and displays a flat or slightly concave valve face. The marine genus Aulacodiscus first appeared in the Cretaceous and is known up to the Recent (Proschkina-Lavrenko 1949; Nikolaev et al. 2001; Sims et al. 2006). It is common in the numerous Late Cretaceous diatom floras of middle and high latitudes, e.g., the Campanian of the Kanguk Formation, Devon Island, Canadian High Arctic (Witkowski et al. 2011), the Maastrichtian Marca Shale Member of the Moreno Formation in California, USA (Nikolaev et al. 2001; Davies 2006), the Campanian-Maastrichtian of the Ural Mountains and the the West Siberian Plain (Strelnikova 1974) and the Campanian-Maastrichtian of Central Russia near Saratov (Oreshkina et al. 2013).

\section{DISCUSSION}

\section{Biostratigraphic framework}

Because of tectonic complications, the three segments of the Chmielnik-Grabówka composite section were studied separately, and then correlated biostratigraphically.

The A. mayaroensis and R. fructicosa zones have been recognized based on the occurrence of their respective index species The $A$. mayaroensis Zone is recognized in two samples of segment $C$, located in the uppermost part of the studied section. The $R$. fructicosa Zone was recognized in all three segments, indicating that they are at least partly coeval (Text-fig. 2). 
The standard foraminiferal zonation by Robaszynski and Caron $(1995$, p. 6) has been modified recently by Ogg and Hinnov (2012, p. 810, fig. 27.6). Above the $A$. mayaroensis Zone, the highest foraminiferal zone of the Maastrichtian in the scheme of Robaszynski and Caron (1995), they propose two additional zones, namely the zones of Pseudoguembelina hariaensis and of Plummerita hantkenionoides. In fact, the $P$. hariaensis Zone was also recognized by Robaszynski and Caron (1995), but in their "heterohelicid" scheme, in a position correlated with the A. mayaroensis Zone of their "globotruncanid" zonation. Both zones never appear in the same standard biozonation. Additionally, between the zones of R. fructicosa and Gansserina gansseri, Ogg and Hinnov (2012) recognize the Pseudoguembelina palpebra Zone. This zone was not used in the Robaszynski and Caron (1995) scheme but it was recognized earlier by $\mathrm{Li}$ and Keller (1998), Huber et al. (2008) and Pèrez-Rodrígues et al. (2012). It seems that Ogg and Hinnov's zonation combines the Tethyan and Boreal schemes, based on globotruncanids and heterohelicids respectively. Such a combination may have, however, rather limited application, as representatives from both domains can co-occur in only restricted areas (ecotones?).

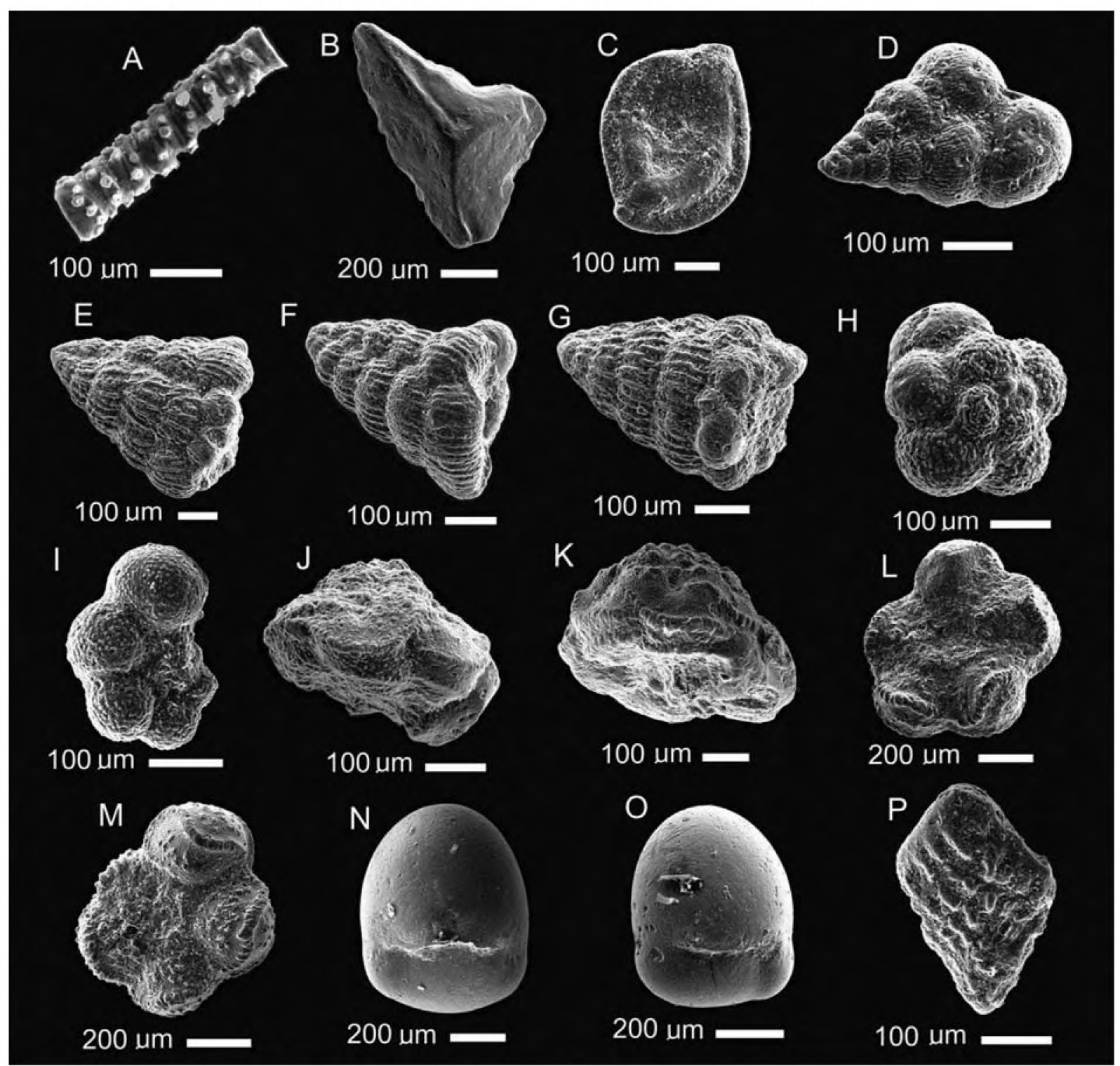

Text-fig. 4. Other microfossils (A, B) and foraminiferids (C-P) from the Chmielnik-Grabówka section. A-fragment of crinoid cirri, sample CG15. B - Fish teeth, sample CG15. C - Rzehakina cf. fissistomata (Grzybowski, sample CG2. D - Heterohelix striata (Ehrenberg), sample CG1. E-G - Racemiguembelina fructicosa (Egger), E - sample CG2, F- sample CG5, G - sample CG12. H - Archaeoglobigerina cretacea (dOrbigny), sample CG1. I-Globigerinelloides prairiehillensis Pessagno, sample CG1. J, K-Contusotruncana contusa (Cushman), sample CG1. L, M-Abathomphalus mayaroensis (Bolli), L - sample CG1, M - sample CG2.

$\mathbf{N}, \mathbf{O}$-Quadrimorphina allomorphinoides (Reuss), N-sample CG2, O-sample CG12. P-Bolivinoides cf. peterssoni Brotzen, sample CG1 


\section{Microfossil palaeoecology}

The analyzed foraminiferal assemblage resembles those reported earlier from the coeval stratigraphic interval of the Skole Nappe (Gaj and Bakowiec sections: Gasiński and Uchman 2009, 2011). The foraminiferids of the Chmielnik-Grabówka section are dominated by planktonic taxa (Text-fig. 2). Similarly to the Bąkowiec section, the number of the epipelagic planktonic taxa (i.e. Heterohelix spp., Globigerinelloides prairiehillensis, Hedbergella holmdelensis, H. monmouthensis, $R$. fructicosa) increases upwards, toward the top of the Maastrichtian (A. mayaroensis Zone), which suggests similar factors influencing depositional environment in the studied part of the Skole Basin (Gasiński and Uchman 2011).

Agglutinated foraminiferids are relatively rare and the suspension feeder morphogroup (sensu Jones and Charnock 1985), Nagy (1992) and Koutsoukos and Hart (1990) dominates. Only samples CG12-CG15 contain relatively abundant agglutinated taxa belonging mainly to the suspension feeder morphogroup (Nothia sp., Rhabdammina sp.), which are typical of environ- ments influenced by turbiditic sedimentation (Gasiński and Uchman 2011 and references therein). Usually, abundance of planktonic foraminiferids is inversely related to the abundance of agglutinated benthic taxa (Gasiński 1998). This inverse relationship is clear in the studied section, suggesting that most of the nutritional suspension was consumed by planktonic taxa, causing a shortage of food for benthic taxa. With respect to palaeobathymetry, calcareous benthic foraminiferids are rare in almost all samples, except for samples CG1 and CG2 (Text-fig. 2) in the topmost Maastrichtian. They display a wide bathymetric range above the calcite compensation depth.

The frustules of the studied diatoms from the Ropianka Formation are large, thick-walled valves, suggesting their benthic affiliation (Sims et al. 2006). Most of the Recent Aulacodiscus species belong to littoral benthic communities, living mainly on sandy substrates and preferentially in warm waters (Hernandez-Becerril et al. 1994). Accordingly, the extinct species of Aulacodiscus may also be regarded as indicative of shallowmarine environments (Proschkina-Lavrenko 1949; Strelnikova 1974; Witkowski et al. 2011).
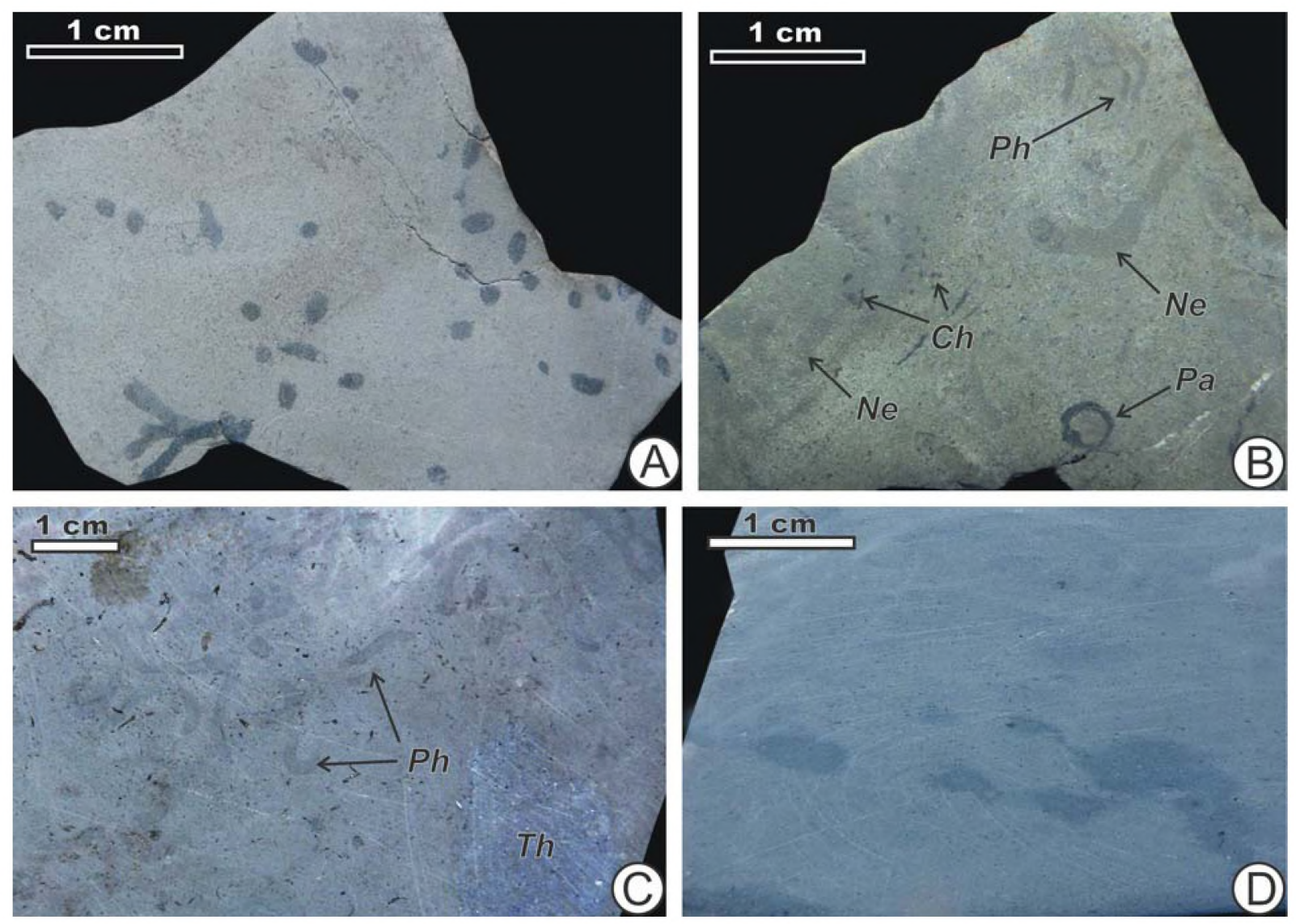

Text-fig. 5. Trace fossils on totally bioturbated background in polished and wet surfaces, Ropianka Formation, Chmielnik-Grabówka section. A-Chondrites isp., marlstone, sample CG11, B - Chondrites isp. (Ch), Nereites irregularis (Ne), Phycosiphon incertum (Ph) and Palaeophycus isp. (Pa), marlstone, sample CG11. C - Phycosiphon incertum $(P h)$ and ?Thalassinoides isp. (Th), marly mudstone, sample CG15A. D-bioturbational structures (?Thalassinoides isp.), marly mudstone, sample CG15D 
The presence of a few fragments of juvenile bivalves, fish teeth and remnants of crinoids, together with benthic and planktonic foraminifers, indicates the presence of rich benthic and pelagic faunal assemblages. However, these fossils could have not been in situ, because the sediments were deposited by density currents, mostly turbidites. Mixing of the microfauna is evident in samples CG8 and CG9, taken from debris flow sediments, where Cretaceous and Palaeogene taxa co-occur [Subbotina cf. yeguaensis (Weinzierl and Applin), Subbotina cf. triloculinoides (Plummer), Schackoina sp.]. These samples are not included in the stratigraphic considerations.

\section{Preservation of diatoms}

Diatoms from samples CG15 and CG15A are pyritized, as indicated by their EDS analysis (Text-fig. 3E). The pyritization was not caused by anoxia on the sea floor, as the presence both of trace fossils (Chondrites, Planolites, Palaeophycus, Phycosiphon incertum, Nereites irregularis, ?Thalassinoides) (Text-fig. 5A-D) and bioturbational structures (probably Thalassinoides) in the diatom-bearing bed (sample CG15B; Text-fig. 3D) indicates an oxygenated sea floor. On the other hand, pyritization could have taken place within the sediment, either below the redox boundary, or in the organic-rich, oxygen-deficient microenvironment within the frustules, as reported from within ammonite shells (Hudson 1980). A shallow depth of the redox boundary is suggested by the dark grey colour of the sediments in sample CG15. However, in sample CG15, pyritized diatoms and some pyritized planktonic foraminiferids co-occur with nonpyritized calcareous tests of planktonic foraminiferids (Text-fig. 2). The pyritization of diatoms can reflect rapid burial in muddy, inner sublittoral environments (e.g. Sims et al. 2006). It is possible that the studied diatoms and some planktonic foraminiferids had already been pyritized in other environments, then exhumed and redeposited in the flysch basin, where they were mixed with non-pyritized microfossils. This may also apply to other pyritized diatoms from the Carpathian Flysch (see Geroch 1978), albeit at least some of them are definitely related to anoxic environments, such as those from the black shales of the Lower Cretaceous (Maslun et al. 1980, p. 79) or from the Lower Oligocene (Senkovsky et al. 2004).

\section{CONCLUSIONS}

The Abathomphalus mayaroensis and Racemiguembelina fructicosa planktonic foraminiferal zones of the
Maastrichtian have been recognized in the ChmielnikGrabówka composite section, based on the occurrence of their respective index species. The former is represented in only two samples from segment $C$, located in the uppermost part of the studied section. The latter zone was recognized in all three segments of the studied section, indicating that they are at least partly coeval. Additionally, pyritized diatoms are present in the $R$. fructicosa Zone, which is an unusual occurrence in Cretaceous flysch microfossil assemblages of the Carpathians. The pyritization was not caused by anoxia, because the presence of trace fossils and bioturbational structures in the diatom-bearing beds indicate an oxygenated sea floor. The pyritization probably took place in the sediment, either below the redox boundary or in the organic-rich, oxygen-deficient microenvironment within the frustules. The redox boundary was located at a shallow depth, as is indicated by the dark grey colour of sediments in sample CG15. In this sample, pyritized diatoms and some pyritized planktonic foraminiferids co-occur with non-pyritized foraminiferids. It is probable that these pyritized microfossils (diatoms and planktonic foraminiferids) had been exhumed from sediments elsewhere, transported, redeposited and mixed with non-pyritized, calcareous tests of foraminiferids.

\section{Acknowledgements}

Micropalaeontological research was sponsored by the Polish National Science Centre, grant NN 307038840. Waldemar Obcowski helped in arrangement of the photographic figures. Zbigniew Sawlowicz provided EDS analysis of the diatom frustules. Nina Strelnikova is sincerely acknowledged for her advice in diatom taxonomy. Irek Walaszczyk, Chris Wood, and two anonymous journal reviewers are thanked for several useful improvements.

\section{REFERENCES}

Arz, J.A. and Molina, E. 2002. Late Campanian and Maastrichtian biostratigraphy and chronostratigraphy based on planktic foraminifera in temperate and subtropical latitudes (Spain, France and Tunisia). Neues Jahrbuch für Geologie und Paläontologie, Monatshefte, 224, 161195.

Ayyad, S.N., Abed, M.M. and Abu Zied, R.H. 1997. Biostratigraphy of the Upper Cretaceous rocks in Gebel ArifElNaga, northeastern Sinai, Egypt, based on benthonic foraminifera. Cretaceous Research, 18, 141-159.

Cetean, C., Balc, R., Kaminski, M.A. and Sorin, F. 2011. Integrated biostratigraphy and palaeoenvironments of an up- 
per Santonian - upper Campanian succession from the southern part of the Eastern Carpathians, Romania. Cretaceous Research, 32, 575-590.

Chlebowski, T., Obultowicz, J. and Wdowiarz, J. 1937. Badania geologiczne zachodnich Karpat brzeżnych w okolicy Rzeszowa, Tyczyna i Ropczyc. Kosmos A, 62, 669-683.

Davies, A. 2006. High resolution palaeoceanography and palaeoclimatology from mid and high latitude Late Cretaceous laminated sediments. Unpublished $\mathrm{PhD}$ thesis, University of Southampton, School of Ocean and Earth Science.

Friedberg, W. 1900. Studya geologiczne w okolicy Rzeszowa i Lańcuta. Kosmos, 24, 289-311.

Friedberg, W. 1903. Atlas Geologiczny Galicyi, Tekst do Zeszytu Szesnastego, 147 pp. Wydawnictwa Komisyi Fizyograficznej Akademii Umiejętności; Kraków.

Gasiński, M.A. 1997. Tethyan-Boreal connection: influence on the evolution of mid-Cretaceous planktonic foraminiferids. Cretaceous Research, 18, 505-514.

Gasiński, M.A. 1998. Campanian-Maastrichtian palaeoecology and palaeobiogeography of the Andrychów Klippes, Outer Carpathians, Poland. Uniwersytet Jagielloński, Rozprawy Habilitacyjne, 333, 1-90.

Gasiński, M.A. and Uchman, A. 2009. Latest Maastrichtian foraminiferal assemblages from the Husów region (Skole Nappe, Outer Carpathians, Poland). Geologica Carpathica, 60, 283-294.

Gasiński, M.A. and Uchman, A. 2011a. Foraminiferal assemblages and the Cretaceous- Paleogene Boundary in turbiditic deposits of the Skole Nappe, Polish Carpathians. In: M. Bąk, M.A., Kaminski and A. Waśkowska (Eds), Integrating microfossil records from the oceans and epicontinental seas. Grzybowski Foundation Special Publications, 17, 87-88.

Gasiński, M.A. and Uchman, A. 2011b. The Cretaceous- Paleogene boundary in turbiditic deposits identified to the bed: a case study from the Skole Nappe (Outer Carpathians, southern Poland). Geologica Carpathica, 62, 333-343.

Geroch, S. 1978. Lower Cretaceous diatoms in the Polish Carpathians. Rocznik Polskiego Towarzystwa Geologicznego, 48, 283-295.

Geroch, S., Krysowska-Iwaszkiewicz, M., Michalik, M., Prochazka, K., Radomski, A., Radwański, Z., Unrug, Z., Unrug, R. and Wieczorek, J. 1979. Sedimentation of the Węgierka marls. Annales Societatis Geologorum Poloniae, 49, 105-133. [In Polish with English summary]

Geroch, S. and Nowak, W. 1980. Stratigraphy of the Flysch in the borehole Lodygowice IG-1 (Western Carpathians). Annales Societatis Geologorum Poloniae, 50, 341-390. [In Polish with English summary]

Gradstein, F.M., Ogg, J.G., Smitz, M.D. and Ogg, G.M. 2012. The Geologic Time Scale, Volumes 1-2, 1176 pp. Elsevier; Amsterdam.
Harwood, D.M. and Nikolaev, V.A. 1995. Cretaceous diatoms: morphology, taxonomy, biostratigraphy. In: C.D. Blome, P.M. Whalen and K.M. Reed (Eds), Siliceous microfossils, Paleontological Society Short Course, 8, 81-106.

Hernandez-Becerril, D.U. and Miranda, N.P. 1994. Morphology and variation of the diatom Aulacodiscus margaritaceus (Bacillariophyta). Acta Botánica Mexicana, 26, $11-19$.

Huber, B., MacLeod, K.G. and Tur, N.A. 2008. Chronostratigraphic framework for upper Campanian-Maastrichtian sediments on the Blake Nose (subtropical North Atlantic). Journal of Foraminiferal Research, 38, 162-182.

Hudson, J.D. 1982. Pyrite in ammonite-bearing shales from the Jurassic of England and Germany. Sedimentology, 29, 639-667.

Jones, R.W. and Charnock, M. 1985. "Morphogroups" of agglutinated foraminifera. Their life position and feeding habits and potential applicability in (paleo)ecological studies. Revue de Paléobiologie, 4, 311-320.

Lohman, K.E. 1960. The ubiquitous diatom - a brief survey of the present state of knowledge. American Journal of Science, Bradley Volume, 258-A, 180-191.

Khalil, H. 1998. Late Cretaceous benthonic foraminiferal biostratigraphy, Sinai, Egypt, with special consideration to the genus Bolivinoides. Neues Jahrbuch für Geologie und Paläontologie, Monatshefte, 7, 415-431.

Kotlarczyk, J. 1978. Stratigraphy of the Ropianka Formation or of Inoceramian Beds in the Skole Unit of the Flysch Carpathians). Prace Geologiczne, Polska Akademia Nauk, Oddziat w Krakowie, Komisja Nauk Geologicznych, 108, 1-82. [In Polish with English summary]

Kotlarczyk, J. 1985. An outline of the stratigraphy if marginal tectonic units of the Carpathian Orogen in the Rzeszów Przemyśl area. In: J. Kotlarczyk, (Ed.), Geotraverse Kraków-Baranów - Rzeszów - Przemyśl - Ustrzyki Dolne Komańcza - Dukla. Guide to excursion 4. CarpathoBalkan Geological Association XIII Congress. Cracow, Poland 1985, pp. 39-63. Geological Institute; Warsaw.

Kotlarczyk, J. 1988. Outline of the stratigraphy of the marginal tectonic units of the Carpathian orogen In: J. Kotlarczyk, K. Pękala, and S. Gucik, (Eds), Przewodnik 59 Zjazdu Polskiego Towarzystwa Geologicznego, Karpaty przemyskie, 16-18 września 1988, p. 23-62. Wydawnictwo AGH, Kraków. [In Polish]

Koutsoukos, E.A.M. and Hart, M.B. 1990. Cretaceous foraminiferal morphogroup distribution patterns, palaeocommunities and trophic structures: a case study from the Sergipe Basin, Brazil. Transactions Royal Society of Edinburgh, Earth Sciences, 81, 221-246.

Kropaczek, B. 1917. Bericht über geologische Ausflüge in der Gegend von Rzeszów. Sprawozdanie Komisyi Fizyograficznej Akademii Umiejętności, 51, 100-105. [In Polish with German summary] 
Li, L. and Keller, G. 1998. Maastrichtian climate, productivity and faunal turnovers in planktic foraminifera in South Atlantic DSDP sites 525A and 21. Marine Micropaleontology, 33, 55-86.

Malata, T. 2001. Jednostka skolska na E od Rzeszowa. Posiedzenia Naukowe Państwowego Instytutu Geologicznego, 57, 60-63.

Maslun, N.V., Selskiy, V.K. and Distryanov, V.M. 1980. Stratigraphic characteristics of the Cretaceous-Paleogene sediments of the first super-deep hole in the Carpathians 1-Shevchenko. Tectonics and Stratigraphy, 18, 72-83. [In Russian]

Murray, J.W. 2006. Ecology and applications of benthic foraminifera, 1-426. Cambridge; University Press Cambridge.

Nagy, J. 1992. Environmental significance of foraminiferal morphogroups in Jurassic North Sea deltas. Palaeogeography, Palaeoclimatology, Palaeoecology, 95, 111-134.

Nederbragt, A.J. 1991. Late Cretaceous biostratigraphy and development of Heterohelicidae (planktonic foraminifera). Micropaleontology, 37, 329-372.

Nikolaev, V.D., Kociolek, J.P., Fourtanier, E., Barron, J. and Harwood, D.M. 2001. Late Cretaceous diatoms (Bacillariophyceae) from the Marca Shale Member of the Moreno Formation, California. Occasional Papers of the California Academy of Sciences, 152, 1-119.

Ogg, J.G.and Hinnov, L.A. 2012. Cretaceous. In: F.M Gradstein, J.G. Ogg, M.D. Smitz and G.M. Ogg. The Geologic Time Scale, 793-853. Elsevier; Amsterdam

Oreshkina, T., Lygina, A., Vozhzhova, O., Ivanov, A. 2013. Diatoms and silicoflagellates of the Upper Cretaceous from Saratov Region: Biostratigraphy and sedimentation settings. Stratigraphy and Geological Correlation, 21, 222236. [In Russian]

Pérez-Rodríguez, I., Lees, J.A., Larrasoaña, J.C., Arz, J.A. and Arenillas, I. 2012. Planktonic foraminiferal and calcareous nannofossil biostratigraphy and magnetostratigraphy of the uppermost Campanian and Maastrichtian at Zumaia, northern Spain. Cretaceous Research, 37, 100-26. Peryt, D., Alegret, L. and Molina, E. 2002. The Creta-
ceous/Palaeogene (K/P) boundary at Aïn Settara, Tunisia: restructuring of benthic foraminiferal assemblages. Terra Nova, 14, 101-107.

Premoli-Silva, I. and Verga, D. 2004. Practical manual of Cretaceous planktonic foraminifera. In: D. Verga and R. Rettori (Eds), International School On Planktonic Foraminifera, $3^{0}$ Course: Cretaceous, pp. 1-283. Universites of Pergugia and Milano; Perugia.

Proschkina-Lavrenko, A.I. 1950. Diatomovyi analiz, opredelitel' iskopaemykh i sovremennykh diatomyk vodoroslei Poriadok Pennales. Gosudarstvennoe Izdatelystvo Geologicheskoi Literatury, Moskva-Leningrad 3, 367398.

Rajchel, J. 1990. Lithostratigraphy of the Upper Paleocene and Eocene deposits in the Skole Unit. Zeszyty Naukowe AGH, Geologia, 48, 1-112. [In Polish with English summary]

Robaszynski, F. and Caron, M. 1995. Foraminiferes planctoniques du Crétacé: commentaire de la zonation EuropeMéditerrané. Bulletin de la Société Géologique de France, 6, 681-692.

Senkovsky, J.M., Grygorchuk, C.G., Hnidets, V.P. and Koltun, Y.V. 2004. Geological Paleoceanography of Tethys (Carpathian - Black Sea segment), 172 pp. Naukova Dumka; Kyiv. [In Ukrainian]

Sims, P., Mann, D.G. and Medlin, L. 2006. Evolution of the diatoms: insights from fossil, biological and molecular data. Phycologia, 45, 361-402.

Strelnikova, N. 1974. Diatomei pozdnego mela, Izdatel'stvo "Nauka", Moskva. [In Russian].

Strelnikova, N., Fourtanier E. and Kociolek P. 2004. Morphological studies of Aulacodiscus species from the "Russian collection" of the California Academy of Sciences. Diatom Research, 19, 238-310.

Wdowiarz, S. 1949. Structure géologique des Karpates Marginales au sud-est de Rzeszów. Biuletyn Państwowego Instytutu Geologicznego, 11, 1-51.

Witkowski, J., Harwood, D.M. and Chin K. 2011, Taxonomic composition, paleoecology and biostratigraphy of late Cretaceous diatoms from Devon Island, Nunavut, Canadian High Arctic. Cretaceous Research, 32, 277-300. 